SVU- International Journal of Veterinary Sciences, 3 (1): 51-65, 2020.

Print ISSN: 2535-1826

Online ISSN: 2535-1877

\title{
Detection of Organochlorine Pesticides Residues in Nile Fish and Its Risks in Qena City
}

\section{Mostafa Abu Elmagd Hassan ${ }^{1}$, Ali Meawad Ahmed ${ }^{2}$, Nabil Mohamed Marzouk ${ }^{3}$, Mohamed Abdelfatah Maky ${ }^{4}$}

${ }^{1}$ Food Control Department, Animal Health Research Institute, Qena. Egypt, ${ }^{2}$ Food Hygiene and Control Department, Faculty of Veterinary Medicine, Suez Canal University, Egypt, ${ }^{3}$ Food Control Department, Animal Health Research Institute, Dokki. Egypt, ${ }^{4}$ Food Hygiene and Control Department, Faculty of Veterinary Medicine, South Valley University,83522, Qena, Egypt.

\section{Abstract}

Fifteen organochlorine pesticides (OCP) residues were determined in Nile tilapia (Oreochromis niloticus), African catfish (Clarias gariepinus) and Long fin catfish (Chrysichthys auratus) in Qena city, Egypt by gas mass chromatography. Nile tilapia fish significantly $(\mathrm{P}<$ 0.05) had the highest concentrations of Dichlorodiphenyldichloroethylene (DDE), endrin, methoxychlor, Dichlorodiphenyldichloroethane (DDD) and endosulfan sulfate with mean \pm SD concentration of $6.27 \pm 0.68,25.02 \pm 0.01,6.98 \pm 1.88, \quad 33.35 \pm 1.76$ and $47.82 \pm 12.51 \mathrm{ppb}$ respectively. Long fin catfish significantly had the highest concentrations of D-chlordane, alpha hexachlorobenzene (a-BHC) and aldrin with mean \pm SD concentration of 82.27 \pm 0.45 , $11.89 \pm 0.56,11.73 \pm 0.48 \mathrm{ppb}$ respectively. Finally, African catfish significantly had the highest concentration of dieldrin with mean concentration $3.53 \pm 0.03 \mathrm{ppb}$ and had significant lowest concentration of endrin $1.99 \pm 1.39 \mathrm{ppb}$. OCP residues in all examined raw fish samples were below the maximum permissible limits (MPL) set by Food and Drug Administration. The effect of pan frying on OCP residues showed that the highest reduction rate in OCP in Nile tilapia was $100 \%$ for dieldrin and endosulfan sulfate while reduction rate in African catfish was $100 \%$ for dieldrin, methoxychlor and endosulfan sulfate. On the other hand, the reduction rate in Long fin catfish was $100 \%$ for dieldrin, endrin, methoxychlor, heptachlor epoxide and endosulfan sulfate. The lowest reduction rate was detected in DDD, DDE, b-BHC, heptachlor and DDT respectively. Consumption of studied fish had no potential hazard to human health as hazard ratio was below one. Carcinogenic risk (CR) value considered acceptable risk for b-BHC and considered level of concern for heptachlor epoxide, total DDTs, lindane and total heptachlor.

Keywords: organochlorine, pesticides, fish.

DOI: $10.21608 / \mathrm{svu} .2020 .19713 .1036$

Received: November 11, 2019

Accepted: January 27, 2020

Published: January 30, 2020

*Corresponding Author: Mostafa Abu Elmagd Hassan E-mail: mostafa.aboalmgd@ vet.svu.edu.eg Citation: Hassan et al., 2020, Detection of Organochlorine Pesticides Residues in Nile Fish and Its Risks in Qena City. SVU-IJVS 2020, 3(1): 51-65.

Copyright: (C) Hassan. This is an open access article distributed under the terms of the creative common attribution license, which permits unrestricted use, distribution and reproduction in any medium provided the original author and source are created.



Competing interest: The authors have declared that no competing interest exists. 


\section{Introduction}

Fish is a desirable and highly nutritive food and considered as a rich source of calcium, phosphorous and vitamins, longchain omega-3 polyunsaturated fatty acids which have many health benefits (Mohamed et al., 2015). Pesticides are substances used to control organisms, including insects, water weeds and plant diseases. Pesticides used in agricultural fields to control pests is extremely toxic to non-target organisms like fish and affects fish health through impairment of metabolism and sometimes leading to death (Shankar et al., 2013). During those days, increased human population with rapid industrialization induced problem of disposal of waste waters. The domestic wastes and untreated or partially treated industrial effluents, supplemented with pollutants like heavy metals, pesticides and many organic compounds lead to massive fish death of aquatic ecosystems (Pazhanisamy and Indra, 2007).

Organochlorines have several forms of toxic effects including effects on liver, immunity reproductive performance and nervous system, viability in addition to skin irritation signs and cancer. They are accused of mimicking the function of hormones and of disrupting the endocrine system (Kallenborn, 2006).

Nile tilapia, African catfish and Long fin catfish are the most common types of fish in Qena city and most consumed fish due to their high palatability and economic price. This study was planned to evaluate OCP concentration in muscle of these fish species and human risk associated with fish consumption.

\section{Materials and Methods \\ Collection of samples:}

One hundred and fifty random samples of three different fish species were random collected from different fish markets in Qena city. Each sample was kept frozen in a separate sterile plastic bag and transferred to the laboratory in an insulated ice box as fast as possible. Average length of Nile tilapia, African catfish and Long fin catfish was 15-20, 2030 and $10-15 \mathrm{~cm}$ respectively while average weights was 150-200, 250-300 and 150-180 g respectively. Initially screened positive samples which contaminated with OCP were heat treated by pan-frying in corn oil at $150 \mathrm{C}$ for 10 minutes (Darwish et al, 2015) to evaluate the reduction rate in OCP concentrations.

\section{Preparation of Samples:}

Fish samples prepared according to (AOAC, 1996). Fish samples were washed several times with deionized water to clean them from sediments and other adhesive materials. The fish samples were identified ,scaled and the heads were removed using a stainless-steel knife, the flesh and other edible portions removed from the bone and entrails. Fifty grams from the dorsal muscle were ground in meat chopper and frozen until analysis and given unique identification codes.

\section{Extraction of OCP:}

One hundred $g$ of anhydrous sodium sulfate were added to combine with water to disintegrate sample with a spatula and blender until well mixed, scrape down the sides of blender jar and break up the caked material with spatula then $150 \mathrm{ml}$ petroleum ether were added and blended at high speed for $2 \mathrm{~min}$. The extract then decanted through $12 \mathrm{~cm}$ Buchner funnel (containing two $12 \mathrm{~cm}$ Whatman filter paper No. 1) into a suction flask. The residue in the blender cup was re-extracted with $75 \mathrm{ml}$ petroleum ether, blended at high speed for 2 minutes decanted through the Buchner funnel and collected with the first extract then the obtained extract was put in rotary evaporator till complete 
evaporation of petroleum ether and obtaining only fat content. Extraction method was done according to (AOAC, 1996).

Clean-up by Petroleum etherAcetonitrile partitioning:

The extracted fat was transferred into $125 \mathrm{ml}$ separatory funnel and $15 \mathrm{ml}$ petroleum ether and $30 \mathrm{ml}$ acetonitrile saturated with petroleum ether were added. Shake the funnel vigorously for $1 \mathrm{~min}$ and hold the separatory funnel in horizontal position and allow the layers to separate then drain the acetonitrile layer (the lower one) into a $1 \mathrm{~L}$ another separatory funnel containing $650 \mathrm{ml}$ distilled water, $40 \mathrm{ml}$ saturated sodium chloride solution and 100 $\mathrm{ml}$ petroleum ether. Set aside thoroughly mixed for 1 minute and leave to separate. Drain the ether layer (the upper one) over cotton wool and anhydrous sodium sulfate conditioned with petroleum ether into 250 $\mathrm{ml}$ round bottom flask and evaporate till complete evaporation of petroleum ether (AOAC, 1996).

\section{Florisil Column Clean-up:}

A glass column $22 \mathrm{~mm}$ internal diameter was prepared, blocked from bottom with glass wool and filled with activated florisil (60-100 mesh pesticides residues grade activated at $130{ }^{\circ} \mathrm{C}$ for 12 hours) to a height of $10 \mathrm{~cm}$ topped with 1 $\mathrm{cm}$ anhydrous sodium sulfate. Pre-wet the column with $40-50 \mathrm{ml}$ petroleum ether then add $2 \mathrm{~g}$ anhydrous sodium sulfate and $20 \mathrm{ml}$ petroleum ether to the obtained petroleum ether solution of sample extract from the above step and then passed through the prepared column at the rate of $5 \mathrm{ml} / \mathrm{minute}$. The column was eluted at the same rate $(5 \mathrm{ml} /$ minute $)$ using $20 \mathrm{ml}$ from every one of three eluting solvents $(6 \%$ diethyl ether in petroleum ether, $15 \%$ diethyl ether in petroleum ether and 50\% diethyl ether in petroleum ether). The eluate was concentrated to a dry film using the rotary evaporator then dissolved in $2 \mathrm{ml}$ n-hexane and transferred into auto sampler vial (AOAC, 1996). The concentrated eluate is now ready for injection into Gas chromatography/Mass Spectroscopy (GC/MS) A TSQ triple quadruple GCMS/MS instrument coupled with a Thermo Scientific TM TRACE TM 1300 GC (Thermo Scientific, Austin, TX, USA) was used. Sample introduction was performed an auto sampler (Thermo Scientific TM AS3000) and chromatographic separation using a Thermo Scientific ${ }^{\mathrm{TM}}$ Trace GOLD TG-5MS $30 \mathrm{ml} \quad 0.25 \mathrm{~mm}$ ID $0.25 \mu \mathrm{m}$ film capillary column. GC/MS and Injector condition were TRACE $1310 \mathrm{GC}, 1.0(\mu \mathrm{l})$ injection volume, Liner SSL single taper $(\mathrm{P} / \mathrm{N}: \quad 453 \mathrm{~A} 2342), \quad 240 \quad\left({ }^{\circ} \mathrm{C}\right)$ inlet temperature, splitless inlet module and mode, carrier gas is $\mathrm{He}, 1.2(\mathrm{ml} / \mathrm{min})$. Oven temperature program is $60\left({ }^{\circ} \mathrm{C}\right)$ for temperature $1,1 \mathrm{~min}$ hold time, $180\left({ }^{\circ} \mathrm{C}\right)$ for temperature 2 with rate $50\left({ }^{\circ} \mathrm{C} / \mathrm{min}\right)$, $320\left({ }^{\circ} \mathrm{C}\right)$ for temperature 3 with Rate 35 $\left({ }^{\circ} \mathrm{C} / \mathrm{min}\right)$ and hold time $4 \mathrm{~min}$.

Mass Spectrometer Condition was TSQ 8000 Evo Mass Spectrometer, 280 $\left({ }^{\circ} \mathrm{C}\right)$ Transfer Line, Ionization type is El, $320\left({ }^{\circ} \mathrm{C}\right)$ Ion source, $70(\mathrm{eV})$ Electron Energy, Acquisition Mode: t-SRM, Q2 Gas Pressure (argon)(psi) is $60,0.7$ (Da) Q1Peak Width and 0.7 (Da) Q3 Peak Width. The pesticide residues were identified based on comparison of relative retention times to those of known standards. Stock standard solutions of pesticide were prepared by dissolving the compound in hexane and stored in amber bottles. Mixed standard solutions were prepared from the individual stock solutions with known concentrations to create the calibration curves at $\mathrm{R}^{\wedge} 2=$ 0.9995. A series of calibration standards were prepared by diluting the mixed standard solution to produce final concentrations in hexane. 


\section{Calculation of organochlorine pesticides:}

$$
C=\frac{\text { peak area }(\text { sample }) \times \text { dilution }(2 \mathrm{ml}) \times \text { standard conc. }(\mathrm{ng})}{\text { peak area }(\text { standard }) \times \text { injection volume }(1 \mu l) \times \text { sample weight }(\mathrm{gm})} \times 1000
$$

Where $\mathrm{C}=$ Concentration of OCP $(\mathrm{ppb})$.

\section{Experimental trial:}

- Experimental part aimed to control of OCP residues in fish by heat treatment. Fish samples contaminated with OCP were treated by pan-frying by cooking the positive fish samples in a hot pan containing a cooking oil (corn oil) at $150 \mathrm{C}$ for 10 minutes then $50 \mathrm{~g}$ of heat treated fish muscle were prepared, extracted and pass through the steps of clean up by petroleum ether- acetonitrile partitioning and florisil column clean up to get the concentrated eluate for injection into GC/MS for detection of pesticides concentrations as mentioned before in preparation and extraction of pesticides in raw fish. Reduction rate \% (R.R) of pesticides due to the effect of heat on OCP residues in fish muscles were calculated according to the following equation:

$$
R . R=\frac{\text { Mean conc. of OCP in raw fish-Mean conc. of OCP in heat treated fish }}{\text { Mean conc. of OCP in raw fish }} \times 100
$$

\section{Human health risk assessment:}

It can be determined through the following parameters:

\section{Estimated Daily Intake (EDI)}

The estimated daily dietary intake of OCPs from fish consumption was calculated according to (WHO, 1987) using the following equation:

\section{$\mathrm{EDI})=\mathrm{C} \times \mathrm{DR}) / \mathrm{BW}$}

Where $\mathrm{C}$ is the concentration of the OCP $(\mathrm{mg} / \mathrm{kg})$ in raw fish, DR is the daily consumption of fish $(\mathrm{Kg} /$ day) and $\mathrm{BW}$ is the average body weight set at $60 \mathrm{~kg}$ (WHO, 2010). The estimated daily consumption rate in Egypt was conservatively set at $48 \mathrm{~g} /$ day per person in Upper Egypt area (FAO, 2003).

\section{Carcinogenic Risk}

Both cancer risk (CR) and hazard ratios (HR) were calculated according to the (USEPA, 2005).

\section{$\mathrm{CR}=\mathrm{EDI} \times \mathrm{CSF}$}

Where CSF is cancer slope factor ( $\mathrm{mg} / \mathrm{kg}$ per day). Its value was 1.6 for HCB, 0.35 for $\Sigma$ CHL 16 for dieldrin, 9.1 for heptachlor epoxide, 1.3 for lindane and 0.34 for $\Sigma$ DDT (USEPA, 2000).

If the CR is more than $10-6$ it is considered 'acceptable risk', between 10-6 and 10-4 are considered 'levels of concern' and a CR smaller than 10-4 is considered" Unacceptable risk' (USEPA, 2005).

\section{The Hazard Ratios (HR)}

To evaluate the potential noncarcinogenic health risk, it was assessed by calculating the hazard index (HI) (US EPA, 1991).

\section{$\mathrm{HI}=\mathrm{EDI} / \mathrm{ADI}$}

Where, EDI; Estimated Daily Intake (mg/ kg bw) and ADI; Acceptable Daily Intake (mg/ kg bw). For a preliminary quantitative risk assessment, a $\mathrm{HI} \leq 0.2$ is considered to indicate negligible adverse health effects as a result of exposure, while HI values exceeding this threshold require a further detailed risk assessment or risk management measures to be undertaken (Health Canada, 2004).

For carcinogenic effects evaluation, hazard ratio (HR) was calculated using the following equation according to (USEPA, 2005) and (Jiang et al. 2005):

\section{$\mathrm{HR}=\mathrm{EDI} / \mathrm{BMC}$}

Where the BMC is the benchmark concentration, derived from the USEPA CSF:

$\mathrm{BMC}=($ Risk $\times \mathrm{BW}) /($ Fish consumption $\times$ CSF)

Where the risk is set at one in a million chances for lifetime exposure, and 
fish consumption is the amount of fish consumed per day $(\mathrm{Kg} / \mathrm{d})$ relative to body weight $(\mathrm{kg})$. An HR greater than one indicates a potential risk to human health (Dougherty et al.2000).

\section{Statistical analysis}

Data obtained from the current study was statistically analyzed by using the Statistical Package for the Social Sciences (SPSS) software (Corp, 2013). A value of $\mathrm{P}<0.05$ was considered significant (Significant at $\mathrm{P}<0.05$ ).

\section{Results}

From the result recorded in table (1) and figure $(1,2,3)$, it was obvious that Alpha-hexachlorocyclohexane (a-BHC) concentrations level were ranged from 0.93-8.42, 0.29-3.75 and 11.14-12.64 ppb with mean value $4.77 \pm 3.59,2.21 \pm 1.43$ and $11.89 \pm 0.56 \mathrm{ppb}$ in Nile tilapia, African catfish and long fin catfish respectively. Beta- hexachlorocyclohexane (b-BHC) concentrations were 4.54-4.65, 4-6.54 and $.21-5.36$ with mean value 4.61 \pm 0.04 , $5.27 \pm 0.92$ and $5.26 \pm 0.06 \mathrm{ppb}$ in Nile tilapia, African catfish and long fin catfish respectively.

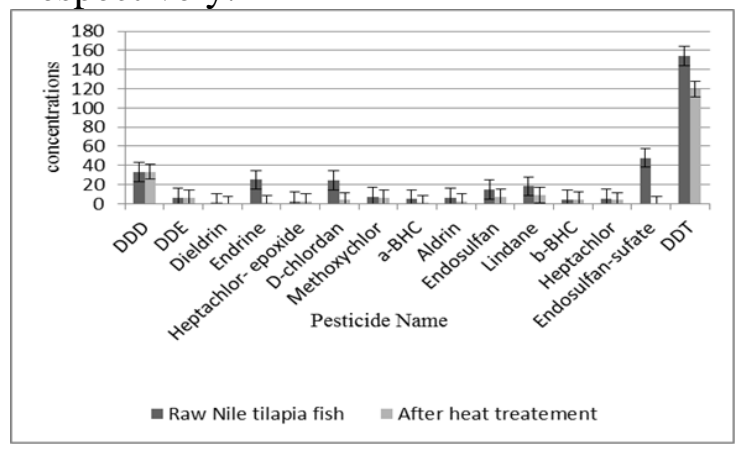

Figure 1. Mean concentration of organochlorine pesticides residues in Tilapia Nilotica fish before and after heat treatment.

Lindane concentrations level were ranged from 8.5-27.86, 28.87-29.32 and17.4-28.68 ppb with mean value $18.18 \pm 9.11,29.11 \pm 0.20$ and $23.03 \pm 4.55$ ppb in Nile tilapia, African catfish and long fin catfish respectively. The highest lindane level was detected in African catfish. Heptachlor mean concentrations were $5.03,4.95 \pm 0.04$ and $4.14 \pm 0.26 \mathrm{ppb}$ in Nile tilapia, African catfish and long fin catfish respectively while heptachlorepoxide mean values were $2.43 \pm 0.01$, $2.37 \pm 0.10$ and $2.53 \pm 0.20 \mathrm{ppb}$ in Nile tilapia, African catfish and long fin catfish respectively. Aldrin mean concentrations were $5.94 \pm 3.67,5.59 \pm 3.18$ and $11.73 \pm 0.48$ ppb in Nile tilapia, African catfish and long fin catfish respectively. The mean concentrations of dieldrin and endrin were ranged from $0.5-3.53$ and $1.99-25.02 \mathrm{ppb}$ respectively.



Figure 2. Mean concentration of organochlorine pesticides residues in African catfish before and after heat treatment.

Chlordane mean concentration was $24.17 \pm 1.15,33.93 \pm 19.57$ and $82.27 \pm 0.45$ ppb in Nile tilapia, African catfish and long fin catfish respectively. The obtained mean concentrations of endosulfan in Nile tilapia, African catfish and long fin catfish were $14.45 \pm 3.12, \quad 15.89 \pm 6.45$ and $12.74 \pm 1.03 \mathrm{ppb}$ and endosulfan sulfate mean concentrations were $47.82 \pm 12.51$, $34.28 \pm 0.27$ and $35 \pm 0.20 \mathrm{ppb}$ respectively. Methoxychlor mean concentrations in Nile tilapia, African catfish and long fin catfish were $6.98 \pm 1.88,1.84 \pm 0.09$ and $0.79 \pm 0.43$ ppb. Total DDTs and its metabolites (DDD, DDE and DDT) concentrations 
were $193.72(33.35,6.27$ and $154.1 \mathrm{ppb})$ in Nile tilapia, 230.44 (30.75, 5.35 and $194.52 \mathrm{ppb}$ ) in African catfish and 234.93 $(30.8,5.56$ and $198.57 \mathrm{ppb})$ in long fin catfish respectively.

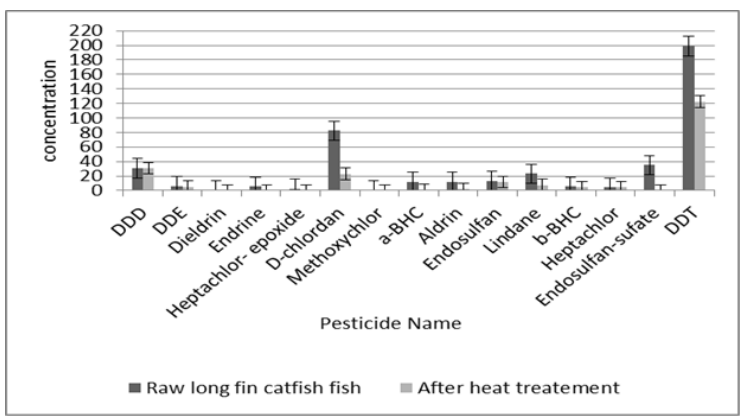

Figure 3. Mean concentration of Organochlorine pesticides residues in long fin catfish before and after heat treatment.

Nile tilapia fish had significantly the highest mean concentration of DDD, DDE, endrin, methoxychlor and endosulfan sulfate and the lowest mean concentration of DDT at $\mathrm{P}<0.05$ among different fish species. African catfish had significantly the highest mean concentration of dieldrin and the lowest mean concentration of endrin among different examined fish species while aldrin, a-BHC and chlordane recorded the most significant highest mean concentration in Long fin catfish comparing with other examined fish species at $\mathrm{P}<0.05$.



Figure 4: Reduction rate of organochlorine pesticides residues in fish species after pan frying.

The results obtained in table (2)and figure (4) revealed that dieldrin and endosulfan sulfate cannot be detected after heat treatment that record $100 \%$ reduction rate(R.R) and the lowest R.R was recorded in DDD, DDE, heptachlor epoxide, b-BHC and methoxychlor with rate varied from 0.12 to $6.59 \%$ in pan-fried Nile tilapia.

Table (2) showed that dieldrin, methoxychlor and endosulfan sulfate were undetected after pan-frying with $100 \%$ R.R while R.R of heptachlor epoxide, endrin, aBHC, lindane, aldrin, endosulfan, D chlorodan, DDT, b-BHC and heptachlor varied from $22.42 \%$ up to $90.72 \%$. The lowest R.R was $0.07 \%$ and $3.93 \%$ for DDD and DDE respectively in pan-fried African catfish.

Pan-frying of long fin catfish reduced five organochlorine pesticides with $100 \%$ R.R including dieldrin, endrin, heptachlor epoxide, methoxychlor and endosulfan sulfate while R.R for a-BHC, aldrin, D chlorodan, lindane, DDT and $\mathrm{b}$-BHC were $92.01,81.93,72.32,68.04,38.35,14.07 \%$ respectively and the lowest R.R was 0.09 , 0.48 and $8.81 \%$ for DDD, heptachlor and DDE respectively.

\section{Discussion:}

In the current study mean value of Alpha-hexachlorocyclohexane (a-BHC) was varied from 2.21 to $11.89 \mathrm{ppb}$ in examined fish species which was below permissible limits (300 ppb) set by FDA (2001). The obtained results were higher than those detected by Abdallah and Morsy (2013) who found a-BHC in catfish and tilapia fish collected from El-Manzala Lake with range of $0.27 \mathrm{ng} / \mathrm{g}$ and 0.17 $37.15 \mathrm{ng} / \mathrm{g}$ respectively while it was lower than the result obtained by Salah El- Dien and Mahmoud (2011) who revealed that concentration of a-BHC was $24.26 \mathrm{ppb}$ in catfish collected from Sharkia market. The obtained results were similar to the results recorded by Abdallah and EL-Greisy (2006) who study the a-BHC concentration in male and female Tilapia zillii in ElManzala Lake (1.8 and 2.2ppb) and El- 
Mekkawi et al.(2009) where mean value of a-BHC varied from 8.5-15.3 ng/g in three fish farms in Sharkia Governorate, Egypt.

Beta-hexachlorocyclohexane (b-BHC) mean value were varied from 4.14-5.27 ppb in fish species which was higher than those detected in catfish, bayad and mackerel measured by Marzouk et al.(2016). It was lower than result of Choudhury et al.(2013) where it ranged from 0.001 to $0.0016 \mu \mathrm{g} / \mathrm{g}$ in five species of fish in Jorhat district of Assam, India. Also, Witczak and Patrzykat (2011) detected b-BHC with range 2.89 to 18.28 (ng/g dry mass) in five fish species in Poland. The obtained results of b-BHC in current study were closely resembled to the values obtained by Salah El- Dien and Mahmoud (2011). On the other hand, Barakat et al.(2017) revealed abnormal high concentration of b-BHC was found in muscle of Mugil species (543 mg/kg w/wt) and in Tilapia $(0.11 \mathrm{mg} / \mathrm{kg} \mathrm{w} / \mathrm{wt})$ collected from Qarun Lake, Egypt which exceeded the maximum residue level recommended by various organizations. Qarun Lake is suffering from serious water pollution problems due to uncontrolled solid and liquid domestic and industrial waste disposal practices, in addition to agrochemical contamination and lack of sustainable wastewater management (Hussein et al. 2008).

\section{Lindane}

(Gamma-

hexachlorocyclohexane) used primarily for controlling wood-inhabiting beetles and as a seed treatment. Lindane is also used as a prescription pharmaceutical to control head lice and mites (scabies) in humans. Lindane mean values were varied from 18.18- $29.11 \mathrm{ppb}$. Its concentration was below permissible limits $(0.3 \mathrm{ppm})$ set by FDA (2001). In current study, the highest concentration of lindane was detected in African catfish. It was higher than results of Daoud et al. (2011) who recorded the mean value $(0.002 \mu \mathrm{g} / \mathrm{kg})$ in Tilapia collected from Qena market, Fianko et al.(2011) who revealed the mean concentration of $\gamma-\mathrm{HCH}$ in examined fish samples collected from Densu river basin in Ghana was $4.94 \mu \mathrm{g} / \mathrm{kg}$ and (Witczak and Patrzykat, 2011) who measured mean concentration of $\gamma-\mathrm{HCH}$ (2.84 to 6.54 ng/g dry mass).

Heptachlor and Heptachlor-epoxide were classified as a probable human carcinogen (B2) by EPA. Heptachlor and Heptachlor-epoxide mean values were varied from 4.14-5.03 and 2.37-2.53 ppb respectively and the detected levels were within the permissible limits (300 ppb) set by FDA (2011) And US-FDA (2000) while those detected by Botaro et al.(2011) were varied from $0.01-0.04 \mu \mathrm{g} / \mathrm{kg}$ in farmed tilapia from Brazilian fish farms. Heptachlor was the highest average concentration $(18.5 \mathrm{ng} / \mathrm{g})$ in catfish samples detected by (Rahmawati et al., 2013). Obtained results were below the average concentrations of heptachlor and heptachlor-epoxide residues in fish samples collected from Damietta while it was close to these concentrations in samples collected from Sohag measured by Morshdy et al. (2018). Elbialy et al. (2015) measured the range of heptachlor (3.210.89) and heptachlor epoxide (15.283.69) $\mu \mathrm{g} / \mathrm{kg}$ in farmed Nile tilapia in Kafr Elsheikh Governorate, Egypt which is higher than current study results.

Aldrin mean concentration was varied from 5.59-11.73 $\mathrm{ppb}$ in examined fish species. It was within permissible limits (0.3 ppm) set by FDA (2001). Aldrin concentration was $2.56 \mu \mathrm{g} / \mathrm{kg}$ measured by Daoud et al.(2011), $0.61 \mathrm{ppb}$ in tilapia 
Table (1) Concentration levels of Organochlorine Pesticides residues ( $\mathrm{ppb}$ ) in raw fish species $(\mathrm{No}=50)$.



collected from Assuit Governorate detected by Yahia and Elsharkawy (2014) and $1.9 \mathrm{ppb}$ estimated by Salah El- Dien and Mahmoud (2011). It was lower than results measured by Eltholth et al. (2018). Aldrin was not detected in fish examined by Morshedy et al.(2018) and Marzouk et al.(2016).

Dieldrin and Endrin EPA has classified endrin as a Group D carcinogen (not classifiable as to human carcinogenicity). Children may be more sensitive to acute endrin exposure than adults, based on effects observed in children during a poisoning incident. Children appeared more susceptible to neurotoxic effects and have exhibited convulsions. The mean concentrations of dieldrin and endrin were ranged from 0.53.53 and 1.99-25.02 ppb respectively. It was within permissible limits detected (300 ppb) set by FDA (2011). Marzouk et al.(2016) did not detect dieldrin in examined fish but endrin mean value was $0.04 \mathrm{ppb}$. Both dieldrin and endrin lower than those exceeded the permissible limits studied by Barakat et al. (2017) where the values were 43.2 and $3260(\mathrm{mg} / \mathrm{kg} \mathrm{ww})$ in muscle of Nile tilapia and 449 and 409 $(\mathrm{mg} / \mathrm{kg}$ wet $\mathrm{ww})$ in Mugil spices from Qarun Lake, Egypt. The obtained value was below the results of El Nahas et al.(2017). Obtained results were match with Eltholth et al.(2018) who measured concentration of diledrin (16.78) and endrin (2.37 ppb) in tilapia from fish farms in Kafrelsheikh governorate which was within maximum permissible limits. Aldrin significant difference among fish samples and the sediments may be due to their specific habitats and feeding habits as well as a higher rate of biotransformation of aldrin to dieldrin and endrin to endrin aldehyde in fish.

Chlordane mean value was ranged from 24.17 to $82.27 \mathrm{ppb}$ in studied fish which was within permissible limits set (300 ppb) set by FDA (2011). It was higher than those measured by Marzouk et al. (2016). Its concentration was below that detected by studied by El Nahas et al.(2017) in Tilapia fish collected from 
Table (2): Organochlorine Pesticides concentration (ppb) in positive samples of fish species after heat treatment $(\mathrm{No}=50) *$ Significant at $\mathrm{P}<0.05$ among different fish species. $\mathrm{R} . \mathrm{R}=$ Reduction Rate of $\mathrm{OCP}$ in fish after pan frying.

\begin{tabular}{|c|c|c|c|c|c|c|c|c|c|c|c|c|c|c|c|}
\hline \multirow[b]{2}{*}{ Pesticide name } & \multicolumn{5}{|c|}{ Heat treated Nile tilapia } & \multicolumn{5}{|c|}{ Heat treated African catfish } & \multicolumn{5}{|c|}{ Heat treated Long fin Catfish } \\
\hline & $\%$ & Min & $\operatorname{Max}$ & Mean \pm SD & R.R\% & $\%$ & Min & Max & Mean \pm SD & R.R\% & $\%$ & Min & $\operatorname{Max}$ & Mean \pm SD & R.R\% \\
\hline DDD & 18 & 31.1 & 35.53 & $33.31 \pm 1.76 *$ & 0.12 & 20 & 30.49 & 30.61 & $30.55 \pm 0.04$ & 0.07 & 14 & 30.67 & 30.89 & $30.77 \pm 0.07 *$ & 0.09 \\
\hline DDE & 18 & 5.12 & 6.98 & $6.04 \pm 0.73 *$ & 3.7 & 20 & 5.08 & 5.18 & $5.14 \pm 0.04 *$ & 3.93 & 14 & 5.01 & 5.11 & $5.07 \pm 0.04 *$ & 8.81 \\
\hline Dieldrin & 14 & 0 & 0 & $0^{*}$ & 100 & 10 & 0 & 0 & $0^{*}$ & 100 & 8 & 0 & 0 & $0^{*}$ & 100 \\
\hline Endrin & 10 & 0.94 & 0.95 & $0.95 \pm 0.004 *$ & 96.2 & 20 & 0 & 0.47 & $0.23 \pm 0.24 *$ & 88.44 & 10 & 0 & 0 & $0^{*}$ & 100 \\
\hline Heptachlor- epoxide & 10 & 2.32 & 2.35 & $2.34 \pm 0.01 *$ & 3.7 & 20 & 0 & 2.21 & $0.22 \pm 0.69 *$ & 90.72 & 14 & 0 & 0 & $0^{*}$ & 100 \\
\hline D-chlordane & 18 & 0 & 18.05 & $4.01 \pm 7.95^{*}$ & 83.41 & 20 & 1.82 & 31.52 & $16.67 \pm 12.66^{*}$ & 50.87 & 4 & 22.11 & 23.42 & $22.77 \pm 0.39 *$ & 72.32 \\
\hline Methoxychlor & 4 & 4.02 & 9.01 & $6.52 \pm 2.35$ & 6.59 & 20 & 0 & 0 & $0 *$ & 100 & 14 & 0 & 0 & $0^{*}$ & 100 \\
\hline $\mathrm{a}-\mathrm{BHC}$ & 12 & 0.85 & 0.91 & $0.88 \pm 0.03$ & 81.55 & 18 & 0 & 0.92 & $0.58 \pm 0.34 *$ & 73.76 & 14 & 0.83 & 1.1 & $0.95 \pm 0.09 *$ & 92.01 \\
\hline Aldrin & 18 & 2.01 & 2.3 & $2.18 \pm 0.12^{*}$ & 63.30 & 20 & 1.1 & 2.13 & $1.62 \pm 0.36^{*}$ & 71.02 & 14 & 2.1 & 2.16 & $2.12 \pm 0.02^{*}$ & 81.93 \\
\hline Endosulfan & 18 & 5.15 & 9.42 & $7.29 \pm 2.08^{*}$ & 49.55 & 20 & 5.87 & 6.43 & $6.11 \pm 0.23 *$ & 61.55 & 14 & 10.65 & 13.23 & $11.88 \pm 1.05^{*}$ & 6.75 \\
\hline Lindane & 16 & 8.41 & 9.15 & $8.86 \pm 0.13$ & 51.27 & 10 & 7.95 & 8.48 & $8.22 \pm 0.25^{*}$ & 71.76 & 14 & 6.4 & 8.56 & $7.36 \pm 0.78^{*}$ & 68.04 \\
\hline b-BHC & 14 & 4.31 & 4.45 & $4.37 \pm 0.05^{*}$ & 5.21 & 20 & 3.12 & 4.64 & $3.85 \pm 0.53 *$ & 26.94 & 14 & 4.43 & 4.72 & $4.52 \pm 0.13^{*}$ & 14.07 \\
\hline Heptachlor & 2 & 3.9 & 3.9 & 3.9 & 22.47 & 10 & 3.8 & 3.89 & $3.84 \pm 0.04 *$ & 22.42 & 14 & 3.9 & 4.41 & $4.12 \pm 0.26$ & 0.48 \\
\hline Endosulfan-sulfate & 18 & 0 & 0 & $0^{*}$ & 100 & 8 & 0 & 0 & $0^{*}$ & 100 & 14 & 0 & 0 & $0^{*}$ & 100 \\
\hline DDT & 18 & 117.89 & 121.48 & $119.69 \pm 1.59^{*}$ & 22.33 & 20 & 116.44 & 120.86 & $118.64 \pm 1.49^{*}$ & 39.01 & 14 & 121.21 & 123.63 & $122.42 \pm 1.01 *$ & 38.35 \\
\hline
\end{tabular}

Burullus Lake. On the other hand, its average value was $10.1(\mathrm{ng} / \mathrm{g} \mathrm{ww})$ in fish sample from Sohag and 16.44(ng/g ww) in fish from Damietta studied by Morshdy et al. (2018). Chlordane used extensively on agricultural crops, livestock, lawns, and for termite control. Because of concern over cancer risk, human exposure, and effects on wildlife, most uses were banned in 1978, and all uses were banned by 1988 (USEPA 2000). Due to its long half-life and ability to concentrate in biological materials, it is still widely distributed in fish in the United States.

Total DDTs included DDT metabolites (sum of DDD, DDE and DDT). In the current study the mean values of total DDTs and its metabolites (DDD, DDE and DDT) were 193.72 (33.35, 6.27 and $154.1 \mathrm{ppb}$ ) in Nile tilapia, 230.44 (30.75, 5.35 and $194.52 \mathrm{ppb})$ in African catfish and 234.93 (30.8, 5.56 and 198.57 $\mathrm{ppb}$ ) in long fin catfish respectively. The obtained results were below permissible limits $(5000 \mathrm{ppb})$ set by (Codex Alimentarius, 1999) while those studied by (Said and Hamed, 2005) were ranged from $161-3100 \mathrm{ng} / \mathrm{g}$ with average $1087 \mathrm{ng} / \mathrm{g}$ in three fish species collected from El Temsah and Bitter Lakes of the Suez Canal so, it exceeded the permissible limits set by various organization. Obtained results were higher than those evaluated by Yahia and Elsharkawy (2014) who estimated pp.DDE in fish in Assuit. It was closely similar to that obtained by Al-Shwafi et al.(2009) who investigated DDTs in imported fish and shellfish from the Gulf of Adan and Red Sea of Yemen Coast. Land based activities result from agricultural and municipal wastes are the main source of pollution by chlorinated pesticides in the Sueza Canal area (Said and Hamed 2005). DDT is generally used against a wide variety of agricultural and forest pests and against insect pests including vectors such as mosquito and tse-tse fly. DDTs had been in continuous use over the past decade for agricultural and public health programs Muralidharan et al.(2009)

OCP contaminants levels can vary significantly within the same fish species depending on the age, the fat content and the area where the fish was caught Pandelova et al.(2008). 
Table (3) Human risk (HR) and Carcinogenic risk (CR) of Organochlorine Pesticides

\begin{tabular}{|l|c|c|c|c|c|c|c|c|c|c|c|}
\hline & & & \multicolumn{3}{|c|}{ EDI } & \multicolumn{3}{c|}{ CR } & \multicolumn{3}{c|}{ HR } \\
\hline pesticide & CSF & ADI & $\begin{array}{c}\text { Nile } \\
\text { Tilapia }\end{array}$ & $\begin{array}{c}\text { African } \\
\text { catfish }\end{array}$ & $\begin{array}{c}\text { Long fin } \\
\text { catfish }\end{array}$ & $\begin{array}{c}\text { Nile } \\
\text { tilapia }\end{array}$ & $\begin{array}{c}\text { African } \\
\text { catfish }\end{array}$ & $\begin{array}{c}\text { long fin } \\
\text { catfish }\end{array}$ & $\begin{array}{c}\text { Nile } \\
\text { tilapia }\end{array}$ & $\begin{array}{c}\text { African } \\
\text { catfish }\end{array}$ & $\begin{array}{c}\text { long fin } \\
\text { catfish }\end{array}$ \\
\hline Dieldrin & 16 & 10000 & $7.5 \mathrm{E}-07$ & $3.53 \mathrm{E}-06$ & $5 \mathrm{E}-07$ & 0.000012 & $5.65 \mathrm{E}-05$ & 0.000008 & 0.0096 & 0.045184 & 0.0064 \\
\hline $\begin{array}{l}\text { Heptachlor } \\
\text { epoxide }\end{array}$ & 9.1 & 5000 & $2.43 \mathrm{E}-06$ & $2.37 \mathrm{E}-06$ & $2.53 \mathrm{E}-06$ & $2.21 \mathrm{E}-05$ & $2.16 \mathrm{E}-05$ & $2.3 \mathrm{E}-05$ & 0.01769 & 0.017254 & 0.018418 \\
\hline D-chlordane & 0.35 & 500 & $2.42 \mathrm{E}-05$ & $3.39 \mathrm{E}-05$ & $8.23 \mathrm{E}-05$ & $8.46 \mathrm{E}-06$ & $1.19 \mathrm{E}-05$ & $2.88 \mathrm{E}-05$ & 0.006768 & 0.0095 & 0.023036 \\
\hline a-BHC & 1.6 & 100 & $4.77 \mathrm{E}-06$ & $2.21 \mathrm{E}-06$ & $1.19 \mathrm{E}-05$ & $7.63 \mathrm{E}-06$ & $3.54 \mathrm{E}-06$ & $1.9 \mathrm{E}-05$ & 0.006106 & 0.002829 & 0.015219 \\
\hline Lindane & 1.3 & 5000 & $1.82 \mathrm{E}-05$ & $2.91 \mathrm{E}-05$ & $2.3 \mathrm{E}-05$ & $2.36 \mathrm{E}-05$ & $3.78 \mathrm{E}-05$ & $2.99 \mathrm{E}-05$ & 0.018907 & 0.030274 & 0.023951 \\
\hline b-BHC & 1.6 & ND & $4.61 \mathrm{E}-06$ & $5.27 \mathrm{E}-06$ & $5.26 \mathrm{E}-06$ & $7.38 \mathrm{E}-06$ & $8.43 \mathrm{E}-06$ & $8.42 \mathrm{E}-06$ & 0.005901 & 0.006746 & 0.006733 \\
\hline Total DDT & 0.34 & 10000 & 0.000194 & 0.00023 & 0.000235 & $6.59 \mathrm{E}-05$ & $7.83 \mathrm{E}-05$ & $7.99 \mathrm{E}-05$ & 0.052692 & 0.06268 & 0.063901 \\
\hline Total heptachlor & 4.5 & 100 & $7.46 \mathrm{E}-06$ & $7.32 \mathrm{E}-06$ & $6.67 \mathrm{E}-06$ & $3.36 \mathrm{E}-05$ & $3.29 \mathrm{E}-05$ & $3 \mathrm{E}-05$ & 0.026856 & 0.026352 & 0.024012 \\
\hline
\end{tabular}

$\mathrm{CSF}=$ cancer slope factor according to US PA (2000).

$\mathrm{ADI}=$ Accepted Daily Intake (ng/kg bw/day) according to WHO (2010).

$\mathrm{EDI}=$ Estimated Daily Intake ( $\mathrm{mg} / \mathrm{kg}$ bw/day).

$\mathrm{CR}=$ Carcinogenic Risk.

$\mathrm{HR}=$ Human Risk.

Bhuiyan et al (2009) stated that DDT and heptachlor are nearly insoluble in water and has a good solubility in most organic solvents, fats and oils. Moreover, these are highly stable molecule. OCP concentrations vary among different fish species, size classes within a fish species, fish tissues, and contaminants present in ecosystems. Chemical contaminants are not bioaccumulated to the same degree in all fish species. In addition, chemical contaminants are not distributed uniformly in fish tissues; some toxicants bind primarily to lipids and others to proteins. Fatty and/or larger fish often contain higher organic contaminant concentrations than leaner and smaller fish US EPA (2000). The nature of catfish habitat which lives in cloudy water and preys on another fish, worm and insects, in addition the high fat contents of catfish meat as previously said are satisfied reasons to explain these relative high frequency and concentrations of OCP residues Salah El- Dien and Mahmoud (2011).

Control of OCP residues in fish species by pan-frying:
Frying is a cooking method in which food is submerged in hot fat, most commonly in cooking oil. Typically, it is a rapid preparation technique that promotes physical and chemical changes in the products and leads to unique sensory properties of color, flavor, texture, palatability and has the greatest effect on nutrient composition in fish because of water loss, fat uptake, and changes in the profile of fatty acids $\mathrm{P}^{\prime}$ erez- Palacios et al.(2014). Pan-frying is cooking the food in a hot pan containing a scant amount of cooking oil. Frying can affect the lipid composition and nutritional value of cooked products compared with those in the raw samples Dom'inguez at al.(2014). The reduction of pesticides is due to loss of lipids during cooking Bayen et al.(2005). Dressing fish that is the removal of head, viscera and tail also influences pesticide values in fish flesh however this depends on the species of fish and fatty fish has higher pesticide values.

The result obtained in table (2) showed the effect of pan-frying on OC pesticides residues in fish. The study revealed that there is significant reduction 
of OCP residues (Significant at $\mathrm{P}<0.05$ ) by pan-frying. The reduction rate of dieldrin, endosulfan sulfate was $100 \%$ in all examined fish species. Methoxychlor reduction rate was $100 \%$ in both African catfish and Long fin catfish. Heptachlor epoxide reduced with rate $100 \%$ in long fin catfish and $96.2 \%$ in Nile tilapia. Endrin reduction rate reach up to $100 \%$ in Long fin catfish only. The lowest reduction rate was detected in DDD, DDE, DDT, b-BHC in all pan-fried fish species.

The obtained results were higher than the study of Witczak (2009) who demonstrated that frying reduced levels of persistent OCP in fish meat by $10-32 \%$ on average. Talab and Ghannam (2015) studied the effect of thermal processing methods microwave and halogen caused significant $(\mathrm{P}<0.05)$ losses in the concentrations of most examined pesticides. Halogen cooking method was more effective than microwave in reducing the content of persistent organochlorine pesticides which is somewhat close to current study. The results detected by Morshdy et al.(2018) demonstrated that Pan-frying had the highest reduction effects on such OCPs. The reduction percentages were $80 \%, 75 \%, 85.5$ and $90 \%$ on the total DDTs, HCHs, HPTs and drins (aldrin and endrin) respectively. Reduction rate in OC varied according to fish species and its locality according to results of Hassanen et al.(2016) who revealed that depletion rate in Tilapia samples from Manzala lake were, 100, 90, 11, 8, 67, 67, $67 \%$ for $\alpha$ BHC, $\beta$ BHC, $\gamma$-chlordane, $\mathrm{HCB}$, heptachlor, aldrin, DDE respectively. Goyal and Aulakh (2017) studied the effect of frying on levels of pesticide residues in 3 fish species and depletion rate was $45.4,40$ to $44.5 \%$ for $\beta$ $\mathrm{HCH}, \gamma-\mathrm{HCH}$ respectively. Finally panfrying has significant reducing effect (Significant at $\mathrm{P}<0.05$ ) of different type of examined OCP and it considers of effective cooking methods to reduce OC pesticides residues in fish.

Human health risk from consumption of fish tissue:

The ADI, EDI, HR and CR were estimated for each fish species .Data obtained in Table (3) showed that hazard ratio (HR) of all studied OCP in all examined raw fish species was less than 1 that ensure consumption of these fish has no potential hazard risk to human health in Qena city. Carcinogenic risk (CR) measured in examined raw fish species and its value considered acceptable risk (more than 10-6) for b-BHC in all examined raw fish species, dieldrin in Long fin catfish, chlordane in Nile tilapia and a-BHC in both Nile tilapia and African catfish while studied CR considered level of concern (between 10-6 and 10-4) for heptachlor epoxide, total DDTs, lindane and total heptachlor in all examined raw fish species. In addition to a-BHC in Long fin catfish, dieldrin in both Nile tilapia and African catfish, chlordane in both African catfish and Long fin catfish also considered level of concern. There is no level of OCP in examined raw fish considered non-acceptable risk (less than 10-4).

\section{Conflict of interest statement}

The authors declare that they have no conflict of interest.

\section{References}

Abdallah AMA, EL-Greisy ZA (2006). Organochlorines and PCBs in tilapia zillii from Lake El-Manzala, Egypt. Chemistry and Ecology, 22(3): 219-224.

Abdallah MAM, Morsy FA (2013). Persistent organochlorine pollutants and metals residues in sediment and freshwater fish species cultured in a 
shallow lagoon, Egypt.

Environmental Technology, 34(16): 2389-2399.

Al-Shwafi N, Al-trabeen K, Rasheed M (2009). Organochlorine pesticides and polychlorinated biphenyls carcinogens residual in some fish and shell fish of Yemen. Jordan Journal of Biological Sciences, 2 (1): $23-28$.

AOAC (Association Official Analytical Chemists) (1996). Official methods of the Association Official Analytical Chemists. Washington, D.C.

Barakat AO, Khairy M, Aukaily I (2017). Bioaccumulation of organochlorine contaminants in fish species from Lake Qarun, a protected area of Egypt. Toxicological and Environmental Chemistry, 99 (1):117-133.

Bayen S, Barlow P, Lee HK, Obbard JP (2005). Effect of cooking on the loss of persistent organic pollutants from salmon. Journal of Toxicology and Environmental Health A 68(4):253-265.

Bhuiyan MNH, Bhuiyan HR, Ahmed K, Dawlatana M, Haque FKM, Rahim M, Bhuiyan MNI (2009). Organochlorine insecticides (DDT and heptachlor) in dry fish: Traditional washing and cooking effect on dietary intake. Journal of the Bangladesh Pharmacological Society, 4: 46-50.

Botaro D, Torres PM, Malm O, Rebelo M.F, Henkelmann B, Schramm KW (2011). Organochlorine pesticides residues in feed and muscle of farmed Nile tilapia from Brazilian fish farms. Food and Chemical Toxicology 49: 21252130.

Choudhury BH, Das BK, Chutia P (2013). Evaluation of pesticide residues in fish tissue samples collected from different markets of Jorhat district of Assam, India. International Journal of Scientific and Engineering Research, 4(12): 22862299.

Codex Alimentarius Commission (1996) and (1999). Pesticides in food: Maximum Residue Limits, Extraneous Maximum Residue Limits.

Corp, IBM (2013). IBM SPSS statistics for windows version 22.0. Armonk, NY: International Business Machines Corp.

Daoud JR, Hegazy HMR, Ahmed AM (2011). Pesticide residues in frozen beef and fresh Tilapia "Oreochromis niloticus" displayed in Qena governorate markets. Conference of South Valley University for Environmental Researches, 1(1):1-7.

Darwish WS, Ikenaka Y, Nakayama S, Mizukawa H, Ishizuka M (2015). Mutagenicity of modelled-heattreated meat extracts: Mutagenicity assay, analysis and mechanism of mutagenesis. Japanese Journal of Veterinary Research 63(4): 173182.

Dom'inguez R, G'omez $M$, Fonseca $S$, Lorenzo JM (2014). Influence of thermal treatment on formation of volatile compounds, cooking loss and lipid oxidation in foal meat. Journal of Food Science and Technology 58:439-445.

Dougherty CP, Holtz SH, Reinert JC, Panyocosit L, Axelrad DA, Woodruff TJ(2000). Dietary exposures to food contaminants across the United States. Environmental Research, 84:170185. 
El Nahas AF, Abdel-Razek MAS, Helmy

NM, Mahmoud S, Ghazy HA (2017). Impaired antioxidant gene expression by pesticide residues and its relation with other cellular biomarkers in Nile Tilapia (Oreochromis niloticus) from Lake Burullus. Ecotoxicology and Environmental Safety,137: 202209.

Elbialy ZI, Ismail T, Abdelhady DH, ElAsely AM (2015). Assessment of genotoxic effects of pesticide residues and related haematobiochemical parameters on Farmed Nile tilapia (Oreochromis Niloticus L.) in Kafrelsheikh governorate, Egypt. Alexandria Journal of Veterinary Sciences, 44: 136-146.

El-Mekkawi H, Diab M, Zaki M, Hassan A (2009). Determination of chlorinated organic pesticide residues in water, sediments, and fish from private fish farms at Abbassa and Sahl Al-Husainia, Shakia governorate . Australian Journal of Basic and Applied Sciences, 3(4): 4376-4383.

Eltholth M, Fornace K, Grace D, Rushton J, HäslerB (2018). Assessing the chemical and microbiological quality of farmed tilapia in Egyptian fresh fish markets. Global Food Security, 17:14-20.

FAO (2003). Nutrition country profilesEgypt. Rome, Italy August 2003

FDA Food and Drug Administration,(2001).

Environmental chemical Contaminant and Pesticide Tolerances, Action Levels and Guidance Levels for fish and fishery products, Compliance Policy Guide Sec.575.100. Pesticide Chemical Residues in
Food- Enforcement Criteria (CPG 7141.01).

FDA Food and Drug Administration, (2011).Fish and Fishery Products Hazards and Controls Guidance .4th Edn. "Compliance Policy Guide," Sec. 575.100.

Fianko JR, Donkor A, Lowor ST, Yeboah PO, Glover ET, Adom T, Faanu A (2011). Health risk associated with pesticide contamination of fish from the Densu river basin in Ghana. Journal of Environmental Protection, 2: 115-123.

Goyal A, Aulakh RK (2017). Effect of processing on pesticide residues in some edible fresh water fishes. Journal of Animal Research, 7 (1) : 191-195.

Hassanen FS, Kamel EA, Gaafar-Rehab AM, Shaheen AA (2016). Effect of grilling on pesticides residues in $\mathrm{O}$. niloticus muscles. Benha Veterinary Medical Journal, 30 (1):348-357.

Health Canada, 2004. Federal contaminated site risk assessment in Canada: Part1: Guidance on human health preliminary quantitative risk assessment (PQRA).

Hussein H, Amer R, Gaballah A, Refaat Y, Abdel-Waha A(2008). Pollution monitoring for Lake Qarun. Advances in Environmental Biology, 2 (2): 70_80.

Jiang QT, Lee TK, Chen K, Wong HL, Zheng JS, Giesy JP, Lo KK, Yamashita N, Lam PK(2005). Human health risk assessment of organochlorines associated with fish consumption in a coastal city in China. Environmental Pollution, 136: $155-165$.

Kallenborn R (2006). Persistent organic pollutants (POPS) as environmental risk factors in remote high-altitude 
ecosystems. Ecotoxicology and Environmental Safety journal, 63: 100-107.

Marzouk NM, Shoukry HM, Ali H, Naser GA, Fayed AMSh (2016). Detection of harmful residues in some fish species. Egyptian Journal of Chemistry and Environmental Health, 2 (2):363 -381.

Mohamed AA, Galal AA, Elewa YH (2015). Comparative protective effects of royal jelly and cod liver oil against neurotoxic impact of tartrazine on male rat pups brain. Acta Histochemica journal,117: 649-658.

Morshdy AEMA, Darwish WS, Daoud JRM, Hussein MAM, Sebak MAM (2018). Monitoring of Organochlorine Pesticide Residues in Oreochromis Niloticus collected from Some Localities in Egypt. Slovenian Veterinary Research, 55(20): 303-311.

Muralidharan S, Dhananjayan V, Jayanthi P (2009).Organochlorine pesticides in commercial marine fishes of Coimbatore, India and their suitability for human consumption. Environmental Research, 109(1):15-21.

Pandelova M, Henkelmann B, Roots O, Simm M, Järv L, Benfenati E, Schramm KW (2008). Levels of $\mathrm{PCDD} / \mathrm{F}$ and dioxin-like $\mathrm{PCB}$ in Baltic fish of different age and gender. Chemosphere, 71: 369-378.

Pazhanisamy K, Indra N (2007). Toxic effects of arsenic on protein content in the fish, labeorhita (Hamilton). Nature Environment and pollution Technology, 6 (1):113-116.

$\mathrm{P}^{\prime}$ erez-Palacios T, Petisca C, Casal S, Ferreira IM (2014). Changes in chemical composition of frozen coated fish products during deepfrying. International Journal of food
Sciences and Nutrition, 65(2):212218.

Rahmawati S, Margana G, Yoneda M, Oginawati K (2013). Organochlorine pesticide residue in Catfish (Clarias sp.) collected from local fish cultivation at Citarum watershed, West Java Province, Indonesia. Procedia Environmental Sciences, 17:3-10.

Said TO, Hamed MAF (2005). Distribution of chlorinated pesticides in surface water and fish of El-Temsah and Bitter lakes, Suez Canal. Egyptian journal of Aquatic Research 31(1): 201-212.

Salah El- Dien WM, Mahmoud HA (2011). Study of some chemical pollutant residues in catfish at Sharkia governorate, Egypt. Journal of American Science, 7(1):386-393.

Shankar KM, Kiran BR, Venkateshwarlu M (2013). A review on toxicity of pesticides in fish. International Journal of Open Scientific Research, 1(1):15-36.

Talab AS, Ghannam HE (2015). Organochlorine pesticide residues in raw and cooked fish fillets .Journal of Biodiversity and Environmental Sciences.7 (3): 292303.

US EPA, 1991. Risk Assessment Guidance for Superfund Volume 1: Human Health Evaluation Manual (Part B), Development of Risk-Based Preliminary Remediation Goals (No. EPA/540/R-92/003).

USEPA United States Environmental Protection Agency, 2000. Guidance for assessing chemical contaminant data for use in fish advisories volume 2 risk assessment and fish consumption limits third edition.

USEPA United States Environmental Protection Agency, 2005. 
Guidelines for carcinogen risk assessment.

US-FDA (2000). Guidance for industry: Action levels for poisonous or deleterious substances in human food and animal feed.

WHO (World Health Organisation), FAO (Food Agriculture Organisation), 1987. Evaluation of Certain Food Additives and Contaminants (Technical Report No. 751). Cambridge University Press.

WHO (World Health Organization), 2010. Inventory of IPCS and other WHO pesticide evaluations and summary of toxicological evaluations performed by the Joint Meeting on Pesticide Residues (JMPRs).
Witczak A (2009). Effect of heat treatment on organochlorine pesticide residues in selected fish species. Polish journal of food and nutrition sciences. 59(3): 231-235.

Witczak A, Patrzykat A (2011). Comparison of two sample preparation methods for analysis of organochlorine pesticides residues in fish muscle. Journal of Environmental Science and Health Part B.46:191-197.

Yahia D, Elsharkawy EE (2014). Multi pesticide and PCB residues in Nile tilapia and catfish in Assiut city, Egypt. Science of the Total Environment. 466:306-314. 